\title{
Structures of Rhodonocardins Produced by a Nocardia sp.
}

\author{
Hideo Etoh, Masanobu Iguchi, Toru Nagasawa, * \\ Yoshiki TANI, ${ }^{* *}$ Hideaki YamadA* \\ and Hiroshi FuKAMI*** \\ Faculty of Pharmaceutical Sciences, Meijo University, \\ Nagoya 468, Japan \\ * Department of Agricultural Chemistry, Kyoto University, \\ Sakyo-ku, Kyoto 606, Japan \\ ** Research Center for Cell and Tissue Culture, Kyoto University, \\ Sakyo-ku, Kyoto 606, Japan \\ *** Pesticide Research Institute, Faculty of Agriculture, Kyoto University, \\ Sakyo-ku, Kyoto 606, Japan \\ Received December 1, 1986
}

\begin{abstract}
Water-soluble wine-colored pigments, rhodonocardins A and B (RN-A and -B), were isolated along with antibiotic sakyomicins from the culture broth of Nocardia sp. Mild acidic hydrolysis of RN-A gave (+)-rhodinose and RN-B. The CMR data suggested RN-A and -B to be glycosides of the same aglycone as that of sakyomicin $A$, except for the presence of a hydroxy group on $C(5)$. The structures of RN-A and -B were determined as Ia and $\mathbf{I b}$, respectively, both of which contain a 1- $\alpha$ 2-deoxy-2-mercaptoglucosyl moiety on $\mathrm{C}(5)$.
\end{abstract}

Bright wine-red colored and water-soluble pigments, rhodonocardins $\mathrm{A}$ and $\mathrm{B}$ (abbreviated to $\mathrm{RN}-\mathrm{A}$ and $-\mathrm{B}$ ), were isolated along with antibiotic sakyomicins ${ }^{1)}$ from a culture broth of Nocardia sp. No. 53. Neither RN-A nor -B showed antibiotic activity to any microorganisms tested. The structures of RN-A and $-\mathrm{B}$ were elucidated by comparing their spectroscopic data and products of chemical degradation with those of sakyomicin A, which had been established to have the structure of II by single-crystal X-ray analysis. ${ }^{1}$

Mild acidic hydrolysis of RN-A gave (+)rhodinose and RN-B in a good yield. Comparing the ${ }^{13} \mathrm{C}$-NMR spectral data of $O$ acetyl-RN-A and -B with those of $O$-triacetylsakyomicin A as shown in Table I, it was suggested that rhodonocardins were glycosides of the same aglycone of sakyomicin A (II), except for the presence of a hydroxyl group on

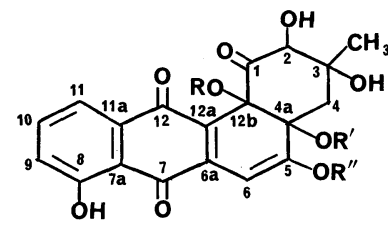

Ia: $\mathbf{R}=(+)$-Rhodinosyl

$\mathbf{R}^{\prime}=1-\alpha-\mathrm{D}-\mathrm{Glucosyl}$

$R^{\prime \prime}=1-\alpha-2$-Deoxy-2-mercaptoglucosyl

Ib: $\mathbf{R}=\mathbf{H}$

$R^{\prime}=1-\alpha-D-G l u c o s y l$

$\mathrm{R}^{\prime \prime}=1-\alpha$-2-Deoxy-2-mercaptoglucosyl

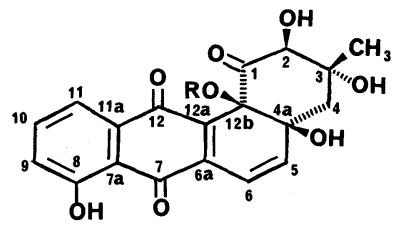

II: $\mathbf{R}=(+)$-Rhodinosyl Sakyomicin A

FIG. 1. Structures of RN-A, RN-B and Sakyomicin A. 
TAble I. Chemical Shifts (ppm from TMS) in the ${ }^{13} \mathrm{C}$-NMR SPECTRUm (in $\mathrm{CDCl}_{3}$ ) OF the $O$-ACETATES OF RHODONOCARDINS AND SAKYOMICIN A

\begin{tabular}{|c|c|c|c|}
\hline Assignment* & $\begin{array}{l}\text { Decaacetate } \\
\text { of RN-A }\end{array}$ & $\begin{array}{l}\text { Nonaacetate } \\
\text { of RN-B }\end{array}$ & $\begin{array}{c}\text { Triacetate } \\
\text { of sakyomicin } \mathrm{A}\end{array}$ \\
\hline 1 & $196.39 \mathrm{~s} * *$ & $199.67 \mathrm{~s}$ & $197.10 \mathrm{~s}$ \\
\hline 2 & $81.03 \mathrm{~d}$ & $80.62 \mathrm{~d}$ & $81.14 \mathrm{~d}$ \\
\hline 3 & $74.65 \mathrm{~s}$ & $74.88 \mathrm{~s}$ & $74.94 \mathrm{~s}$ \\
\hline 3-Me & $22.93 \mathrm{q}$ & $23.23 \mathrm{q}$ & $22.52 \mathrm{q}$ \\
\hline 4 & $45.11 \mathrm{t}$ & $45.52 \mathrm{t}$ & $43.29 \mathrm{t}$ \\
\hline $4 a$ & $79.10 \mathrm{~s}$ & $77.75 \mathrm{~s}$ & $76.76 \mathrm{~s}$ \\
\hline 5 & $159.24 \mathrm{~s}$ & $158.78 \mathrm{~s}$ & $145.85 \mathrm{~d}$ \\
\hline 6 & $107.94 \mathrm{~d}$ & $108.35 \mathrm{~d}$ & $117.42 \mathrm{~d}$ \\
\hline $6 a$ & $137.01 \mathrm{~s}$ & $137.89 \mathrm{~s}$ & $137.60 \mathrm{~s}$ \\
\hline 7 & $181.77 \mathrm{~s}$ & $181.48 \mathrm{~s}$ & $182.18 \mathrm{~s}$ \\
\hline $7 \mathrm{a}$ & $122.68 \mathrm{~s}$ & $122.80 \mathrm{~s}$ & $122.68 \mathrm{~s}$ \\
\hline 8 & $149.77 \mathrm{~s}$ & $149.77 \mathrm{~s}$ & $149.59 \mathrm{~s}$ \\
\hline 9 & $129.88 \mathrm{~d}$ & $129.88 \mathrm{~d}$ & $129.93 \mathrm{~d}$ \\
\hline 10 & $135.67 \mathrm{~d}$ & $135.61 \mathrm{~d}$ & $135.90 \mathrm{~d}$ \\
\hline 11 & $125.78 \mathrm{~d}$ & $125.31 \mathrm{~d}$ & $125.84 \mathrm{~d}$ \\
\hline $11 \mathrm{a}$ & $133.50 \mathrm{~s}$ & $133.62 \mathrm{~s}$ & $135.43 \mathrm{~s}$ \\
\hline 12 & $181.18 \mathrm{~s}$ & $181.18 \mathrm{~s}$ & $181.18 \mathrm{~s}$ \\
\hline $12 \mathrm{a}$ & $132.39 \mathrm{~s}$ & $131.92 \mathrm{~s}$ & $133.39 \mathrm{~s}$ \\
\hline $12 \mathrm{~b}$ & $81.32 \mathrm{~s}$ & $77.75 \mathrm{~s}$ & $80.73 \mathrm{~s}$ \\
\hline$(\mathrm{R})$ & $16.32 \mathrm{q}$ & - & $16.21 \mathrm{q}$ \\
\hline (R) & $22.52 \mathrm{t}$ & - & $22.52 \mathrm{t}$ \\
\hline (R) & $23.69 \mathrm{t}$ & - & $23.75 \mathrm{t}$ \\
\hline (R) & $65.99 \mathrm{~d}$ & - & $65.76 \mathrm{~d}$ \\
\hline (R) & $68.68 \mathrm{~d}$ & - & $69.03 \mathrm{~d}$ \\
\hline (R) & $94.54 \mathrm{~d}$ & - & $94.37 \mathrm{~d}$ \\
\hline$(\mathrm{G})$ & $48.56 \mathrm{~d}$ & $47.56 \mathrm{~d}$ & - \\
\hline (G) & $61.84 \mathrm{t} \times 2$ & $61.90 \mathrm{t} \times 2$ & - \\
\hline (G) & $68.33 \mathrm{~d}$ & $68.39 \mathrm{~d}$ & - \\
\hline (G) & $68.68 \mathrm{~d} \times 2$ & $68.68 \mathrm{~d}$ & - \\
\hline (G) & & $68.86 \mathrm{~d}$ & - \\
\hline (G) & $69.56 \mathrm{~d}$ & $69.38 \mathrm{~d}$ & - \\
\hline (G) & $69.91 \mathrm{~d} \times 2$ & $69.97 \mathrm{~d} \times 2$ & - \\
\hline (G) & $70.91 \mathrm{~d}$ & $71.43 \mathrm{~d}$ & - \\
\hline (G) & $91.97 \mathrm{~d}$ & $92.55 \mathrm{~d}$ & - \\
\hline (G) & $93.60 \mathrm{~d}$ & $94.48 \mathrm{~d}$ & - \\
\hline (Ac-Me) & $20.65 \mathrm{q} \times 6$ & $20.59 \mathrm{q} \times 8$ & $20.89 \mathrm{q} \times 2$ \\
\hline (Ac-Me) & $20.89 \mathrm{q} \times 3$ & & \\
\hline (Ac-Me) & $21.18 \mathrm{q}$ & $21.12 \mathrm{q}$ & $21.00 \mathrm{q}$ \\
\hline \multirow[t]{2}{*}{$(\mathrm{Ac}-\mathrm{CO})$} & 169.07 & $169.25^{2}$ & 169.13 \\
\hline & $\sim 170.89 \mathrm{~s} \times 10$ & $\sim 170.77 \mathrm{~s} \times 9$ & $\sim 170.65 \mathrm{~s} \times 3$ \\
\hline
\end{tabular}

* (R) carbon in the rhodinosyl moiety; $(\mathrm{G})$ carbon in the glucosyl moiety; (Ac-Me) carbon of the acetyl methyl; (Ac-CO) carbon of the acetyl carbonyl; numerical number: carbon in the aglycone skeleton (cf. Fig. 1).

** $\quad \mathrm{s}$, singlet; $\mathrm{d}$, doublet; $\mathrm{t}$, triplet; $\mathrm{q}$, quartet.

C(5) (see Fig. 1). In the ${ }^{13} \mathrm{C}-\mathrm{NMR}$ of $O$ decaacetyl RN-A (Table I), signals for three quaternary carbons [C(3), C(4a) and C(12b)] were observed at around $80 \mathrm{ppm}(74.65,79.10$ and $81.32 \mathrm{ppm})$. A C-H long-range coupling was observed between the signal at $79.10 \mathrm{ppm}$ and the 6-H signal (6.75 ppm), and also between the signal at $74.65 \mathrm{ppm}$ and the $3-\mathrm{CH}_{3}$ signal $(1.32 \mathrm{ppm})$. Therefore the remaining signal at $81.32 \mathrm{ppm}$ was assigned to $\mathrm{C}(12 \mathrm{~b})$. 
Table II. Chemical Shifts (ppm from TMS) IN THE ${ }^{1} \mathrm{H}-\mathrm{NMR}$ Spectrum (in $\mathrm{CDCl}_{3}$ ) OF $O$-NONAACETYL-RN-B

\begin{tabular}{|c|c|c|}
\hline 1.28 & $(3 \mathrm{H}, \mathrm{s}) \ldots$ & 3-Me \\
\hline 1.87 & $(2 \mathrm{H}$, br. s) & $\mathrm{C}(4)-\mathrm{H}$ \\
\hline 1.96 & $(9 \mathrm{H}, \mathrm{s})]$ & \\
\hline 1.97 & $(3 \mathrm{H}, \mathrm{s})$ & \\
\hline 2.00 & $(3 \mathrm{H}, \mathrm{s})$ & \\
\hline 2.04 & $(3 \mathrm{H}, \mathrm{s})$ & Ac-Me \\
\hline 2.06 & $(3 \mathrm{H}, \mathrm{s})$ & \\
\hline 2.20 & $(3 \mathrm{H}, \mathrm{s})$ & \\
\hline 2.45 & $(3 \mathrm{H}, \mathrm{s})]$ & \\
\hline 3.11 & $(1 \mathrm{H}$, br. s) & $\mathrm{OH}$ \\
\hline 3.67 & $(1 \mathrm{H}, \mathrm{dd}, J=11.0 \mathrm{~Hz}, 3.6 \mathrm{~Hz}) \quad \ldots$ & $\mathrm{C}\left(2^{\prime}\right)-\mathrm{H}$ \\
\hline $3.95 \sim 4.08$ & 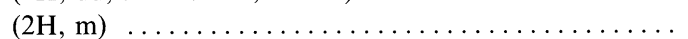 & $\mathrm{C}\left(5^{\prime}, 6^{\prime}\right)-\mathrm{H}$ \\
\hline $4.10 \sim 4.16$ & $(2 \mathrm{H}, \mathrm{m}) \ldots \ldots \ldots \ldots \ldots$ & $\mathrm{C}\left(6^{\prime \prime}\right)-\mathrm{H}$ \\
\hline 4.22 & $(1 \mathrm{H}, \mathrm{dd}, J=12.0 \mathrm{~Hz}, 6.2 \mathrm{~Hz}) \ldots \ldots$. & $\mathrm{C}\left(6^{\prime}\right)-\mathrm{H}$ \\
\hline 4.32 & $(1 \mathrm{H}$, ddd, $J=10.0 \mathrm{~Hz}, 4.0 \mathrm{~Hz}, 3.0 \mathrm{~Hz})$ & $\mathrm{C}\left(5^{\prime \prime}\right)-\mathrm{H}$ \\
\hline 4.57 & 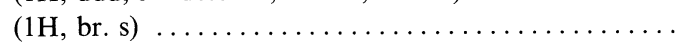 & $\mathrm{OH}$ \\
\hline 5.00 & $(1 \mathrm{H}, \mathrm{dd}, J=9.6 \mathrm{~Hz}, 3.9 \mathrm{~Hz}) \ldots \ldots \ldots \ldots \ldots \ldots$ & $\mathrm{C}\left(2^{\prime \prime}\right)-\mathrm{H}$ \\
\hline 5.04 & $(1 \mathrm{H}, \mathrm{dd}, J=10.0 \mathrm{~Hz}, 9.6 \mathrm{~Hz})$ & $\mathrm{C}\left(4^{\prime \prime}\right)-\mathrm{H}$ \\
\hline 5.10 & $(1 \mathrm{H}, \mathrm{dd}, J=10.0 \mathrm{~Hz}, 9.6 \mathrm{~Hz})$ & $\mathrm{C}\left(4^{\prime}\right)-\mathrm{H}$ \\
\hline 5.25 & $(1 \mathrm{H}, \mathrm{d}, J=3.6 \mathrm{~Hz}) \ldots \ldots \ldots$ & $\mathrm{C}\left(1^{\prime}\right)-\mathrm{H}$ \\
\hline 5.27 & $(1 \mathrm{H}, \mathrm{d}, J=3.9 \mathrm{~Hz}) \ldots \ldots \ldots \ldots \ldots \ldots \ldots \ldots \ldots \ldots \ldots \ldots \ldots \ldots \ldots \ldots$ & $\mathrm{C}\left(1^{\prime \prime}\right)-\mathrm{H}$ \\
\hline 5.39 & $(1 \mathrm{H}, \mathrm{dd}, J=9.6 \mathrm{~Hz}, 9.6 \mathrm{~Hz}) \ldots \ldots \ldots \ldots \ldots \ldots \ldots$ & $\mathrm{C}\left(3^{\prime \prime}\right)-\mathrm{H}$ \\
\hline 5.40 & $(1 \mathrm{H}, \mathrm{dd}, J=11.0 \mathrm{~Hz}, 9.6 \mathrm{~Hz}) \ldots \ldots \ldots$ & $\mathrm{C}\left(3^{\prime}\right)-\mathrm{H}$ \\
\hline 5.48 & $(1 \mathrm{H}, \mathrm{s}) \ldots \ldots \ldots \ldots \ldots \ldots$ & $\mathrm{C}(2)-\mathrm{H}$ \\
\hline 6.67 & $(1 \mathrm{H}, \mathrm{s}) \ldots \ldots \ldots \ldots \ldots$ & $\mathrm{C}(6)-\mathrm{H}$ \\
\hline 7.33 & $(1 \mathrm{H}, \mathrm{dd}, J=8.0 \mathrm{~Hz}, 1.0 \mathrm{~Hz}) \ldots \ldots \ldots \ldots \ldots$ & $\mathrm{C}(11)-\mathrm{H}$ \\
\hline 7.70 & $(1 \mathrm{H}, \mathrm{dd}, J=8.0 \mathrm{~Hz}, 8.0 \mathrm{~Hz}) \ldots \ldots \ldots \ldots \ldots \ldots$ & $\mathrm{C}(10)-\mathrm{H}$ \\
\hline 7.99 & $(1 \mathrm{H}, \mathrm{dd}, J=8.0 \mathrm{~Hz}, 1.0 \mathrm{~Hz}) \ldots \ldots \ldots \ldots \ldots \ldots$ & $\mathrm{C}(9)-\mathrm{H}$ \\
\hline
\end{tabular}

The corresponding signal was shifted to 77.75 ppm in the ${ }^{13} \mathrm{C}$-NMR of $O$-nonaacetyl RN-B (see Table I), indicating that the rhodinosyl moiety was attached to $\mathrm{C}(12 \mathrm{~b})$ in $\mathrm{RN}-\mathrm{A} .{ }^{2)}$

In the ${ }^{1} \mathrm{H}$-NMR spectrum of $O$-nonaacetylRN-B (Table II), two anomeric proton signals (5.25 and $5.27 \mathrm{ppm}$ ) and their coupling constants $(3.6$ and $3.9 \mathrm{~Hz})$ indicate that the RN-B molecule contained two $\alpha$-glucosyl moieties. The fact that one of these anomeric proton signals at $5.25 \mathrm{ppm}$ was coupled with the signal at $3.67 \mathrm{ppm}$, which was unusually shifted to a higher magnetic field, suggested the possibility for the presence of a thio group in the C-2' position. The ${ }^{13} \mathrm{C}-\mathrm{NMR}$ spectrum of $O$ nonaacetyl-RN-B (see Table I) indicates the presence of a $\mathrm{C}\left(2^{\prime}\right)$ signal at $47.56 \mathrm{ppm}$ in the glucose moiety. In a selective decoupling experiment with ${ }^{13} \mathrm{C}-\mathrm{NMR}$, irradiation of 3.67 ppm resulted in the change of the doublet signal at $47.56 \mathrm{ppm}$ into a singlet. These NMR data may suggest that RN-B contained a 2deoxy-2-mercaptoglucose moiety in the molecule.

$\mathrm{RN}-\mathrm{B}$ was refluxed in $2 \mathrm{~N} \mathrm{HCl}$ for $1.5 \mathrm{hr}$ to give D-glucose and deglucosyl-RN-B. The ${ }^{13} \mathrm{C}$ NMR data of the $O$-hexaacetyl derivative of the latter compound (Table III) suggest that it had a linear structure (IV), which would result from the rearrangement of the original angular structure (III) as shown in Fig. 2. The same rearrangement has been reported in cases of aquayamycin and others having the structure of hydrobenz $[a]$ anthraquinone. ${ }^{3 \sim 5)}$ The fact that this rearrangement could take place only when RN-B was vigorously hydrolyzed shows that the glucosyl moiety was attached to $\mathrm{C}(4 \mathrm{a})$ of the aglycone.

The high-resolution MS of the hexaacetate of deglucosyl-RN-B indicated the presence of a sulfur atom $[\mathrm{m} / \mathrm{z} 758.1528$; calcd. value 758.1514 for $\left.\mathrm{C}_{35} \mathrm{H}_{34} \mathrm{O}_{17} \mathrm{~S} \quad\left(\mathrm{M}^{+}-60\right)\right]$. 


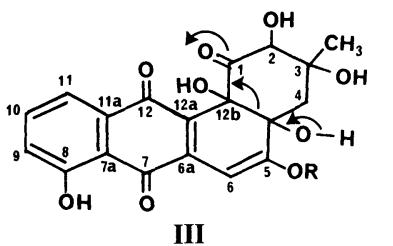

III

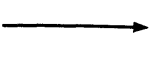

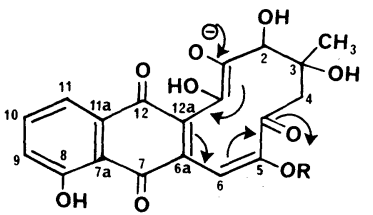

$R=1-\alpha-2-$ deoxy-2-mercaptoglucosyl<smiles>[2H]C12C=C3C(=O)c4c(O)cccc4C(=O)C3=C(O)C1(O)C(O)C(C)(O)CC2=O</smiles>

IV

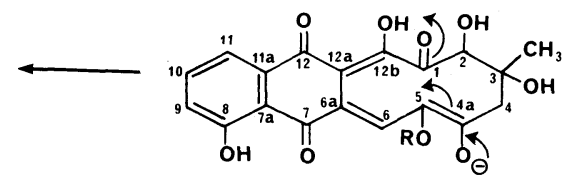

FIG. 2. Rearrangement of Deglucosyl-RN-B to the Linear Compound (IV).

TABle III. Chemical Shifts (ppm from TMS) In THE ${ }^{13} \mathrm{C}-\mathrm{NMR}$ Spectrum (in $\mathrm{CDCl}_{3}$ ) of the HeXaAcetate of Deglucosyl-RN-B

\begin{tabular}{|c|c|c|c|c|}
\hline $\begin{array}{l}\text { Observed } \\
\text { signals }\end{array}$ & Multiplicity & $\begin{array}{l}\text { Assignment for linear } \\
\text { structure IV }\end{array}$ & $\begin{array}{l}\text { Possible } \\
\text { angular }\end{array}$ & $\begin{array}{l}\text { Chemical shifts } \\
\text { for structure III* }\end{array}$ \\
\hline 76.70 & $\mathrm{~s}$ & 1 & $12 b$ & 77.75 \\
\hline 73.71 & $\mathrm{~d}$ & 2 & 2 & 80.62 \\
\hline 76.70 & $\mathbf{s}$ & 3 & 3 & 74.88 \\
\hline 22.47 & $q$ & 3-Me & 3-Me & 23.23 \\
\hline 43.23 & $\mathrm{t}$ & 4 & 4 & 45.52 \\
\hline 200.49 & $\mathrm{~s}$ & $4 a$ & 1 & 199.67 \\
\hline 78.98 & $\mathrm{~s}$ & 5 & $4 a$ & 77.75 \\
\hline 119.29 & $\mathrm{~d}$ & 6 & 6 & $108.35^{* *}$ \\
\hline 131.10 & $\mathrm{~s}$ & $6 a$ & $6 a$ & 137.89 \\
\hline 192.24 & $\mathrm{~s}$ & 7 & 7 & $181.48 * *$ \\
\hline 123.91 & $\mathrm{~s}$ & $7 a$ & $7 \mathrm{a}$ & 122.80 \\
\hline 145.85 & $\mathrm{~s}$ & 8 & 8 & 149.77 \\
\hline 130.17 & d & 9 & 9 & 129.88 \\
\hline 131.34 & d & 10 & 10 & 135.61 \\
\hline 127.36 & $\mathrm{~d}$ & 11 & 11 & 125.31 \\
\hline 125.78 & $\mathrm{~s}$ & $11 \mathrm{a}$ & $11 \mathrm{a}$ & 133.62 \\
\hline 192.24 & $\mathrm{~s}$ & 12 & 12 & $181.18^{* *}$ \\
\hline 129.12 & s & $12 a$ & $12 \mathrm{a}$ & 131.92 \\
\hline 141.23 & $\mathrm{~s}$ & $12 b$ & 5 & $158.78^{* *}$ \\
\hline 91.44 & $\mathrm{~d}$ & $1^{\prime}$ & & 92.55 \\
\hline 43.53 & $\mathrm{~d}$ & $2^{\prime}$ & & 47.56 \\
\hline 68.68 & $\mathrm{~d}$ & $3^{\prime}$ & & 68.86 \\
\hline 69.85 & $\mathrm{~d}$ & $4^{\prime}$ & & 69.38 \\
\hline 70.79 & $\mathrm{~d}$ & $5^{\prime}$ & & 69.97 \\
\hline 61.49 & $\mathrm{t}$ & $6^{\prime}$ & & 61.90 \\
\hline
\end{tabular}

* Based on the signals observed in the ${ }^{13} \mathrm{C}-\mathrm{NMR}$ Spectrum of $O$-acetyl-RN-B (see Table I).

** Large discrepancy with the observed chemical shift.

Consequently, the molecular formulae of $\mathrm{RN}$ $A$ and $-\mathrm{B}$ were assigned to be $\mathrm{C}_{37} \mathrm{H}_{46} \mathrm{O}_{20} \mathrm{~S}$ (SIMS: $m / z$ 843, $\mathrm{M}^{+}+1$ ) and $\mathrm{C}_{31} \mathrm{H}_{36} \mathrm{O}_{18} \mathrm{~S}$
(SIMS: $m / z 729, \mathbf{M}^{+}+1$ ), respectively.

In the ${ }^{1} \mathrm{H}-\mathrm{NMR}$ of $O$-nonaacetyl-RN-B, a significant nuclear Overhauser effect was ob- 
served between the signal of the $\mathrm{C}\left(2^{\prime}\right)$ proton at $3.67 \mathrm{ppm}$ and the signal of the $\mathrm{C}(6)$ proton at $6.67 \mathrm{ppm}$, indicating that the $1^{\prime}-\alpha-2^{\prime}$-deoxy$2^{\prime}$-mercaptoglucosyl group was attached to $\mathrm{C}(5)$ of the aglycone. The possibility of the 5deoxy-5-mercaptoglucosyl moiety instead of the 2-deoxy-2-mercaptoglucosyl was also excluded by the fact that the signal for $\mathrm{C}(1)$ of authentic pentaacetyl-5-deoxy-5-mercapto- $\alpha$ glucose was observed at $73.13 \mathrm{ppm}$ in the ${ }^{13} \mathrm{C}$ NMR spectrum, while the signal for $\mathrm{C}\left(1^{\prime}\right)$ of $O$-nonaacetyl RN-B was found at either 92.55 or $94.48 \mathrm{ppm}$ (see Table I).

From these experimental results, the structure Ia can be assigned to RN-A and Ib to RNB.

\section{EXPERIMENTAL}

Spectral analyses. All the melting points (mp) were measured with a Shimadzu or Yanagimoto melting point apparatus, and were uncorrected. Infrared (IR) spectra were recorded on a Shimadzu IR-400 spectrophotometer. Ultraviolet (UV) spectra were taken on a Shimadzu UV240 spectrophotometer. Optical rotation data were taken on JASCO DIP-SL and JASCO ORD Model J-5 spectropolarimeters. ${ }^{1} \mathrm{H}$ - and ${ }^{13} \mathrm{C}$-NMR spectra were taken on a Hitachi R-22 (90 MHz), JEOL JNM-PS $100(100 \mathrm{MHz})$, Bruker WH-270 (270 MHz), JEOL JNM-FX 100 $(25.0 \mathrm{MHz})$ or JEOL JNM-GX $400(400 \mathrm{MHz})$. Chemical shifts are given in ppm from tetramethylsilane (TMS) as an internal standard. Coupling constants are given in $\mathrm{Hz}$ (s, singlet; d, doublet; $\mathrm{t}$, triplet; q, quartet; m, multiplet). Mass spectra (MS) were recorded on a Hitachi M-52 or M-80B (in-beam EI and CI) mass spectrometer operating at an ionization energy of $70 \mathrm{eV}$. Molecular secondary ion mass spectra (SIMS) were also taken on a Hitach M-80B mass spectrometer.

Preparative high-performance liquid chromatography (HPLC) was carried out on a stainless column $[8 \mathrm{~mm} \phi \times$ $300 \mathrm{~mm}$; Nucleosil $\left.\mathrm{C}_{18}(10 \mu \mathrm{m})\right]$ using an Altex Model $110 \mathrm{~A}$ pump and JASCO UVIDEC 100-II UV detector $(290 \mathrm{~nm})$.

Isolation of rhodonocardin $A(R N-A)$ and rhodonocardin $B(R N-B){ }^{6)} \mathrm{RN}-\mathrm{A}$ and $\mathrm{RN}-\mathrm{B}$ showed the same $R f$ value $\left[R f=0.30, n-\mathrm{BuOH}-\mathrm{AcOH}-\mathrm{H}_{2} \mathrm{O} \quad(4: 1: 1)\right] . \mathrm{RN}-\mathrm{A}$ and RN-B were separated by preparative HPLC [solvent, $\mathrm{MeOH}-\mathrm{H}_{2} \mathrm{O}(20: 80)$; flow rate, $4.0 \mathrm{ml} / \mathrm{min}$. ( $V_{\mathrm{R}}$ value of $\mathrm{RN}-\mathrm{A}=78.0 \mathrm{ml} ; V_{\mathrm{R}}$ value of $\left.\mathrm{RN}-\mathrm{B}=52.0 \mathrm{ml}\right)$

RN-A: $m p 214 \sim 215^{\circ} \mathrm{C},[\alpha]_{\mathrm{D}}^{20}+29^{\circ}(c=0.1, \mathrm{MeOH})$; UV (MeOH) $\lambda: 298$ ( $\varepsilon$ 10,000), 436 shoulder $(\varepsilon 6000)$ and $504(\varepsilon 6700) \mathrm{nm}$; IR (KBr) v: 3350 br., 1730 and 1625 $\mathrm{cm}^{-1} ;{ }^{1} \mathrm{H}-\mathrm{NMR} 100 \mathrm{MHz}\left(\mathrm{CD}_{3} \mathrm{COOD}\right) \delta: 0.59(3 \mathrm{H}, \mathrm{d}$,
$J=6 \mathrm{~Hz}), 1.27(3 \mathrm{H}, \mathrm{s}), 1.8 \sim 2.4(6 \mathrm{H}$, overlapped with solvent signal), $3.3 \sim 4.4(14 \mathrm{H}, \mathrm{m}), 4.47(1 \mathrm{H}, \mathrm{s}), 5.24(1 \mathrm{H}$, br.s), $5.32(1 \mathrm{H}$, br.s), $5.42(1 \mathrm{H}$, br.s), $6.77(1 \mathrm{H}, \mathrm{s})$, $7.0 \sim 7.8(3 \mathrm{H}, \mathrm{m}) .{ }^{1} \mathrm{H}-\mathrm{NMR} 90 \mathrm{MHz}\left(\mathrm{CD}_{3} \mathrm{OD}\right) \delta: 0.55$ $(3 \mathrm{H}, \mathrm{d}, J=7 \mathrm{~Hz}), 1.20(3 \mathrm{H}, \mathrm{s}), 4.22(1 \mathrm{H}, \mathrm{s}), 5.13(1 \mathrm{H}, \mathrm{d}$, $J=3 \mathrm{~Hz}), 5.28(1 \mathrm{H}, \mathrm{br} . \mathrm{s}), 5.36(1 \mathrm{H}, \mathrm{d}, J=3 \mathrm{~Hz})$. The other signals were broad and not well defined. MS: $m / z 843$ $\left(\mathrm{MH}^{+}\right)$(SIMS), $\mathrm{C}_{37} \mathrm{H}_{46} \mathrm{O}_{20} \mathrm{~S}$.

RN-B: $\mathrm{mp} 223^{\circ} \mathrm{C},[\alpha]_{\mathrm{D}}^{20}+29^{\circ}(c=0.1, \mathrm{MeOH})$; UV $(\mathrm{MeOH}) \lambda: 293(\varepsilon 13,000), 438$ shoulder $(\varepsilon 8000)$ and $491(\varepsilon$ $9600) \mathrm{nm}$; IR (KBr) v: $3350 \mathrm{br}, 1730$ and $1625 \mathrm{~cm}^{-1} \cdot{ }^{1} \mathrm{H}$ NMR $100 \mathrm{MHz}\left(\mathrm{CD}_{3} \mathrm{COOD}\right) \delta: 1.27(3 \mathrm{H}, \mathrm{s}), 1.8 \sim 2.4$ $(2 \mathrm{H}$, overlapped with solvent signal), $3.6 \sim 4.2(12 \mathrm{H}, \mathrm{m})$, $4.62(1 \mathrm{H}, \mathrm{s}), 5.26(1 \mathrm{H}, \mathrm{d}, J=3 \mathrm{~Hz}), 5.48(1 \mathrm{H}, \mathrm{br} . \mathrm{s}), 6.76$ $(1 \mathrm{H}, \mathrm{s}), 7.29(1 \mathrm{H}, \mathrm{d}, J=10 \mathrm{~Hz}), 7.57(1 \mathrm{H}, \mathrm{d}, J=8 \mathrm{~Hz}), 7.68$ $(1 \mathrm{H}, \mathrm{m}) .{ }^{1} \mathrm{H}-\mathrm{NMR} 90 \mathrm{MHz}\left(\mathrm{CD}_{3} \mathrm{OD}\right) \delta: 1.20(3 \mathrm{H}, \mathrm{s}), 4.31$ $(1 \mathrm{H}, \mathrm{s}), 5.13(1 \mathrm{H}, \mathrm{d}, J=3 \mathrm{~Hz}), 5.36(1 \mathrm{H}, \mathrm{d}, J=3 \mathrm{~Hz})$. The other signals were broad and not well defined. MS: $m / z$ $729\left(\mathrm{MH}^{+}\right)$(SIMS), $\mathrm{C}_{31} \mathrm{H}_{36} \mathrm{O}_{18} \mathrm{~S}$.

Acid hydrolysis of $R N-A$ (formation of $R N-B$ and (+)rhodinose). A solution of RN-A (100 mg) in $2 \mathrm{~N}$ hydrochloric acid $(6 \mathrm{ml})$ was stirred at room temperature for $1 \mathrm{hr}$. The reaction solution was concentrated under reduced pressure below $40^{\circ} \mathrm{C}$, and then separated by preparative HPLC [Nucleosil $\mathrm{C}_{18}\left(10 \mu \mathrm{m} ; \mathrm{MeOH}-\mathrm{H}_{2} \mathrm{O}\right.$ $(20: 80)]$ to give RN-B $(69 \mathrm{mg})$.

The identification of the sugar was commenced by stirring a solution of RN-A $(98 \mathrm{mg})$ in $2 \mathrm{~N}$ hydrochloric acid $(6 \mathrm{ml})$ at room temperature for $1 \mathrm{hr}$. Dimethyl sulfoxide $(6 \mathrm{ml}), 2 \mathrm{~N}$ hydrochloric acid $(2 \mathrm{ml})$ and 2,4-dinitrophenylhydrazine $(210 \mathrm{mg})$ were added to the reaction solution, which was then allowed to stand at room temperature for $24 \mathrm{hr}$, before being extracted with benzene. The benzene extract was dried over anhydrous $\mathrm{Na}_{2} \mathrm{SO}_{4}$ and filtered. The filtrate was then separated by preparative TLC [Kieselgel $\mathrm{PF}_{254}$; benzene-AcOEt $(1: 3)$ ] to afford the 2,4-dinitrophenylhydrazone of (+)-rhodinose $(24 \mathrm{mg})$. Optical rotation $\left[[\alpha]_{\mathrm{D}}^{20}+15.5^{\circ}(c=1.6\right.$, pyridine $\left.)\right]$ and the spectral data were identical with those of the 2,4-DNP derivative of authentic $(+)$-rhodinose ${ }^{1)}(2,3,6$-trideoxy-Dthreo-aldohexose).

Acetylation of $R N-A$. RN-A ( $319 \mathrm{mg}$ ) was dissolved in pyridine $(30 \mathrm{ml})$ and acetic anhydride $(3 \mathrm{ml})$, and allowed to stand overnight. The ether extract of the reaction solution was washed with $3 \mathrm{~N} \mathrm{HCl}$ and sat. $\mathrm{NaCl}$ solution, dried over anhydrous $\mathrm{Na}_{2} \mathrm{SO}_{4}$, and filtered. The filtrate was concentrated under a reduced pressure and then separated by preparative TLC [Kieselgel $\mathrm{PF}_{254}$; benzeneAcOEt $(1: 2)$ ] to afford the decaacetate of RN-A $(114 \mathrm{mg})$, $\mathrm{mp} 159 \sim 160^{\circ} \mathrm{C}$. UV $(\mathrm{MeOH}) \lambda: 291(\varepsilon 11,000), 311$ shoulder $(\varepsilon 9100)$ and $480(\varepsilon 5600) \mathrm{nm}$. IR (KBr) $v: 3480 \mathrm{br}$, 1750,1665 and $1595 \mathrm{~cm}^{-1} .{ }^{1} \mathrm{H}-\mathrm{NMR} 400 \mathrm{MHz}\left(\mathrm{CDCl}_{3}\right) \delta$ : $0.53(3 \mathrm{H}, \mathrm{d}, J=6.8 \mathrm{~Hz}), 1.32(3 \mathrm{H}, \mathrm{s}), 1.7 \sim 1.9(4 \mathrm{H}, \mathrm{m})$, $1.98(6 \mathrm{H}, \mathrm{s}), 2.01(3 \mathrm{H}, \mathrm{s}), 2.03(3 \mathrm{H}, \mathrm{s}), 2.04(3 \mathrm{H}, \mathrm{s}), 2.08$ $(3 \mathrm{H}, \mathrm{s}), 2.11(3 \mathrm{H}, \mathrm{s}), 2.13(3 \mathrm{H}, \mathrm{s}), 2.26(3 \mathrm{H}, \mathrm{s}), 2.51(3 \mathrm{H}, \mathrm{s})$, 
$3.29(1 \mathrm{H}$, br.s, OH), $3.59(1 \mathrm{H}, \mathrm{m}), 3.72(1 \mathrm{H}, \mathrm{dd}, J=$ $11.5 \mathrm{~Hz}, 3.4 \mathrm{~Hz}), 4.06 \sim 4.20(4 \mathrm{H}, \mathrm{m}), 4.29(1 \mathrm{H}, \mathrm{dd}, J=$ $12.6 \mathrm{~Hz}, 6.2 \mathrm{~Hz}), 4.41(1 \mathrm{H}$, br. d), $4.58(1 \mathrm{H}$, br. s), $5.06(1 \mathrm{H}$, $\mathrm{dd}, J=10.2 \mathrm{~Hz}, 3.9 \mathrm{~Hz}), 5.12(1 \mathrm{H}, \mathrm{dd}, J=10.2 \mathrm{~Hz}, 9.3 \mathrm{~Hz})$, $5.19(1 \mathrm{H}, \mathrm{dd}, J=9.5 \mathrm{~Hz}, 9.5 \mathrm{~Hz}), 5.31(1 \mathrm{H}, \mathrm{d}, J=3.7 \mathrm{~Hz})$, $5.34(1 \mathrm{H}, \mathrm{d}, J=3.7 \mathrm{~Hz}), 5.46(1 \mathrm{H}, \mathrm{d}, J=1.5 \mathrm{~Hz})$, $5.48 \sim 5.51(2 \mathrm{H}, \mathrm{m}), 5.50(1 \mathrm{H}, \mathrm{s}), 6.75(1 \mathrm{H}, \mathrm{s}), 7.39(1 \mathrm{H}, \mathrm{dd}$, $J=7.9 \mathrm{~Hz}, 1.2 \mathrm{~Hz}), 7.77(1 \mathrm{H}, \mathrm{dd}, J=7.9 \mathrm{~Hz}, 7.9 \mathrm{~Hz}), 8.10$ $(1 \mathrm{H}, \mathrm{dd}, J=7.9 \mathrm{~Hz}, 1.2 \mathrm{~Hz}) .{ }^{13} \mathrm{C}-\mathrm{NMR}$ : see Table II.

Acetylation of $R N-B$. A solution of RN-A (400 mg) in $2 \mathrm{~N}$ hydrochloric acid $(10 \mathrm{ml})$ was allowed to stand overnight. The reaction solution was treated according to the same procedure as that for RN-A to afford the nonaacetate of RN-B $(56 \mathrm{mg}), \mathrm{mp} 158 \sim 159^{\circ} \mathrm{C}$; UV $(\mathrm{MeOH})$ $\lambda: 289$ ( $\varepsilon 12,000), 310$ shoulder $(\varepsilon$ 8900) and $470(\varepsilon$ $5700) \mathrm{nm}$. IR $\left(\mathrm{CHCl}_{3}\right)$ v: 3400 br., 1750,1665 and 1590 $\mathrm{cm}^{-1} \cdot{ }^{1} \mathrm{H}-$ and ${ }^{13} \mathrm{C}-\mathrm{NMR}$ : see Tables I and II, respectively.

Acetylation of sakyomicin $A .{ }^{1)}$ Under the same conditions as those for RN-A, acetylation of sakyomicin A $(50 \mathrm{mg})$ gave the triacetate of sakyomicin A $(36 \mathrm{mg}), \mathrm{mp}$ $205 \sim 206^{\circ} \mathrm{C}$; UV $(\mathrm{MeOH}) \lambda: 254$ ( $\varepsilon$ 9100), 305 shoulder $(\varepsilon$ $3100)$ and $357(\varepsilon$ 2500) nm. IR (KBr) $v$ : 3480 br., 1770, 1735 and $1660 \mathrm{~cm}^{-1} .{ }^{1} \mathrm{H}-\mathrm{NMR} 100 \mathrm{MHz}\left(\mathrm{CDCl}_{3}\right) \delta: 0.54$ $(3 \mathrm{H}, \mathrm{d}, J=6 \mathrm{~Hz}), 1.31(3 \mathrm{H}, \mathrm{s}), 1.87(2 \mathrm{H}, \mathrm{m}), 1.98(3 \mathrm{H}, \mathrm{s})$, $2.24(3 \mathrm{H}, \mathrm{s}), 2.44(3 \mathrm{H}, \mathrm{s}), 1.7 \sim 2.4(4 \mathrm{H}, \mathrm{m}), 3.21(1 \mathrm{H}, \mathrm{br} . \mathrm{s}$, $\mathrm{OH}), 3.72(1 \mathrm{H}, \mathrm{m}), 4.65(1 \mathrm{H}, \mathrm{br} . \mathrm{s}), 5.42(1 \mathrm{H}, \mathrm{d}), 5.44(1 \mathrm{H}$, s), $6.37(1 \mathrm{H}, \mathrm{d}, J=9 \mathrm{~Hz}), 6.84(1 \mathrm{H}, \mathrm{d}, J=9 \mathrm{~Hz}), 7.40(1 \mathrm{H}$, br. d, $J=7 \mathrm{~Hz}), 7.76(1 \mathrm{H}, \mathrm{dd}, J=7 \mathrm{~Hz}, 7 \mathrm{~Hz}), 8.10(1 \mathrm{H}$, br. d, $J=7 \mathrm{~Hz}$ ). MS (CI-MS, $\mathrm{NH}_{3}$ gas): $m / z \quad 630$ $\left[\left(\mathrm{M}+\mathrm{NH}_{4}\right)^{+}\right]$.

Acid hydrolysis of $R N-B$ and subsequent acetylation (formation of the hexaacetate of deglucosyl- $R N-B$ and ethyl tetra-O-acetyl-D-glucopyranoside). A solution of RN-B $(200 \mathrm{mg})$ in $2 \mathrm{~N}$ hydrochloric acid $(5 \mathrm{ml})$ was refluxed for $1.5 \mathrm{hr}$. The reaction mixture was concentrated after adding ethanol and benzene under reduced pressure, and then separated by column chromatography [Kieselgel $\left.\mathrm{PF}_{254}, n-\mathrm{BuOH}-\mathrm{AcOH}-\mathrm{H}_{2} \mathrm{O}(4: 1: 1)\right]$ into two fractions containing crude deglucosyl RN-B and the sugar compounds, respectively.

The deglucosyl RN-B fraction was acetylated by adding pyridine and acetic anhydride to give the hexaacetate of deglucosyl-RN-B ( $59 \mathrm{mg})$, which was further purified by preparative TLC [Kieselgel $\mathrm{PF}_{254}$, benzene-AcOEt (1:1)] to afford crystalline deglucosyl RN-B hexaacetate, mp $134 \sim 135^{\circ} \mathrm{C}(12 \mathrm{mg})$.

The fraction containing the sugar compounds was acetylated by the same treatment to give the acetylated product $(50 \mathrm{mg})$, which was purified by repeated preparative TLC on a Kieselgel $\mathrm{PF}_{254}$ plate developed with benzene-AcOEt $(5: 1)$ to give two compounds, their $R f$ values being 0.54 and 0.46 , respectively, with a $6 \mathrm{mg}$ yield of each. These samples were identical with the $\alpha$ - and $\beta$ derivatives of ethyl tetra- $O$-acetyl-D-glucopyranoside, respectively, regarding their optical rotation and NMR spectral data.

Hexaacetate of deglucosyl-RN-B: mp $134 \sim 135^{\circ} \mathrm{C}$. UV $(\mathrm{MeOH}) \lambda: 243$ ( $\varepsilon 16,500), 284$ shoulder $(\varepsilon 18,500), 292(\varepsilon$ $21,000), 319$ shoulder $(\varepsilon 8900), 332$ shoulder $(\varepsilon 7700)$ and $404(\varepsilon 4500) \mathrm{nm}$. IR (KBr) v: 3450 br., 1750, 1695 and $1670 \mathrm{~cm}^{-1} \cdot{ }^{1} \mathrm{H}-\mathrm{NMR} 400 \mathrm{MHz}\left(\mathrm{CDCl}_{3}\right) \delta: 1.16(3 \mathrm{H}$, br. s), $2.01(3 \mathrm{H}, \mathrm{s}), 2.06(3 \mathrm{H}, \mathrm{s}), 2.10(3 \mathrm{H}, \mathrm{s}), 2.23(3 \mathrm{H}, \mathrm{s}), 2.35$ $(3 \mathrm{H}, \mathrm{s}), 2.36(3 \mathrm{H}, \mathrm{s}), 2.01 \sim 2.36(2 \mathrm{H}$, superimposed on MeO signals), $2.88(1 \mathrm{H}, \mathrm{dd}, J=10.6 \mathrm{~Hz}, 2.1 \mathrm{~Hz}), 3.83(1 \mathrm{H}$, m), $4.09 \sim 4.28(3 \mathrm{H}, \mathrm{m}), 4.19(1 \mathrm{H}$, br. s), $5.06(1 \mathrm{H}, \mathrm{dd}, J=$ $9.6 \mathrm{~Hz}, 9.6 \mathrm{~Hz}), 5.31(1 \mathrm{H}, \mathrm{dd}, J=10.6 \mathrm{~Hz}, 9.6 \mathrm{~Hz}), 5.41$ $(1 \mathrm{H}, \mathrm{d}, J=2.1 \mathrm{~Hz}), 5.75(1 \mathrm{H}, \mathrm{br}, \mathrm{s}), 6.47(1 \mathrm{H}, \mathrm{s}), 7.22(1 \mathrm{H}$, br. d, $J=8.0 \mathrm{~Hz}), 7.41(1 \mathrm{H}, \mathrm{dd}, J=8.0 \mathrm{~Hz}, 8.0 \mathrm{~Hz}), 7.90$ $\left(1 \mathrm{H}\right.$, br. d, $J=8.0 \mathrm{~Hz}$ ). MS $m / z: 818\left(\mathrm{M}^{+}\right.$) (in-beam EI). High-resolution MS: $m / z$ 758.1528; calcd. for $\mathrm{C}_{35} \mathrm{H}_{34} \mathrm{O}_{17} \mathrm{~S}$, $758.1514\left(\mathrm{M}^{+}-60\right)$.

Acknowledgments. We thank Dr. T. Mitsudo and Professor K. Koshimizu of Kyoto University, Dr. T. Higashijima and Professor T. Miyazawa of the University of Tokyo, Drs. M. Haruna, M. Niwa, Y. Terada and H. Tanino of Meijo University for NMR measurements, and Dr. K. I. Harada and Professor M. Suzuki of Meijo University for molecular SIMS measurements and discussions. We also thank Drs. T. Ueno and R. Nishida of Kyoto University for their valuable discussions.

\section{REFERENCES}

1) H. Irie, Y. Mizuno, I. Kouno, T. Nagasawa, Y. Tani, H. Yamada, T. Taga and K. Osaki, J. Chem. Soc., Chem. Commun., 1983, 174; T. Nagasawa, H. Fukao, H: Irie and H. Yamada, J. Antibiot., 37, 693 (1984).

2) R. Kasai, M. Suzuo, J. Asakawa and O. Tanaka, Tetrahedron Lett., 1977, 175; K. Tori, S. Seno, Y. Yoshimura, H. Arita and Y. Tomita, J. Am. Chem. Soc., 100, 3331 (1978).

3) M. Sezaki, S. Kondo, K. Maeda and H. Umezawa, Tetrahedron, 26, 5171 (1970).

4) S. Matsumura, Y. Ezure, M. Ozaki, K. Kumagai and H. Matsunaga, Chem. Abstr., 86, 104,453s (1977).

5) T. Kitahara, H. Naganawa, T. Okazaki, Y. Okami and H. Umezawa, J. Antibiot., 28, 280 (1975).

6) H. Yamada et al., unpublished. 